\title{
Reconsidering the Challenges of Earmarked Taxes for Highways
}

David Gellman

\begin{abstract}
A prominent theme in US federal infrastructure policy is the near-term insolvency of the Highway Trust Fund (HTF), the dedicated financing stream for highways and public transit. The HTF is projected to exhaust its reserves by 2022 and require more than $\$ 170$ billion in cumulative general revenue transfers by 2029 , leading to widespread funding uncertainty for nationally-significant surface transportation infrastructure and a dramatic increase in the national debt. This paper examines three countries-Japan, England, and Australia-that chose to eliminate earmarked taxes for highways and examines whether their infrastructure benefited as a result. International outcomes were mixed as to whether federal investments in highways and road quality remained robust following the intervention. But such a solution, with stringent safeguards, could provide an answer to the HTF solvency issue in upcoming surface transportation reauthorization legislation.
\end{abstract}


Despite bipartisan interest in infrastructure reform, there is little agreement on how to accomplish it. Members of Congress, the President, and leaders on both sides of the aisle generally agree that our aging infrastructure needs a significant federal investment in order to achieve a state of good repair, clear a multimillion-dollar maintenance backlog, and meet the economic challenges of the future. However, views differ widely as to whether and how the government will be able to regularly fund the American transportation network for generations to come.

Specifically, the Highway Trust Fund (HTF), the dedicated financing source for the construction and maintenance of surface transportation, is nearing insolvency, meaning that obligations from the Fund will soon exceed revenues flowing into it. According to projections from the Congressional Budget Office, by 2029 the HTF would face a cumulative shortfall of $\$ 171$ billion in order to meet its obligations (CBO 2019). The most widely-discussed solution to maintain the solvency of the HTF is to raise or index the tax on gasoline that is its main source of income, which has remained at 18.4 cents per gallon since 1993 (PGPF 2018a). But lawmakers across the political spectrum have so far been unwilling to enact such a policy. Therefore, the United States must find an alternative intervention that can balance the future solvency of highway programs with political expediency.

International examples from different parts of the world can provide a model for a potential solution to highway financing issues facing the United States. Japan, England, and Australia each chose to address concerns with their highway trust funds by eliminating their earmarked infrastructure revenue streams entirely. Rather than dedicate transportation-related taxes directly to highway systems, these countries send gasoline, toll, and associated revenue to general accounts where expenditures are then allocated through their annual budget and appropriations processes. This paper analyzes these cases in order to determine whether this approach is a useful model for the US to finance comprehensive infrastructure reform.

This analysis seeks to answer the following questions: first, whether an insolvency crisis similar to that in the United States caused lawmakers to eliminate their trust funds for federal highway expenditures; and second, if these initiatives led to improved infrastructure, funding certainty, and greater fairness for those that use and benefit from the road system. Fairness here refers to the "intergenerational equity of public debt," where present-day users of government services pay for them instead of future generations (Catrina 2013). The paper begins by detailing the legislative history of the American HTF in order to understand the rationale behind the system and the causes of the present-day funding imbalance. It then analyzes similar legislative contexts and conditions in Japan, England, and Australia that led to initiatives to eliminate earmarked revenue streams for highways and discusses whether these interventions produced positive results. It concludes with implications for US policy design as legislators in Congress draft the newest measure to reauthorize federal programs governing the surface transportation network. Unless otherwise noted, all dollar amounts in this paper use US dollars.

\section{US HIGHWAY TRUST FUND: LEGISLATIVE HISTORY AND CURRENT STATUS}

The Highway Trust Fund is divided into a Highway Account for highway funding - the primary subject of this paper-and a Mass Transit Account for transit funding. The Highway 
Account is funded by a dedicated revenue stream of transportation-related excise taxes that are earmarked by statute for surface transportation. Taxes on gasoline and diesel fuels account for approximately 85 percent of the account's total revenues, with taxes on certain vehicles and tires making up the remainder (Kile 2015,4). Such trust fund arrangements with dedicated revenues are known outside of the United States as hypothecation and serve as the foundation for similar mechanisms that fund US Social Security, Medicare, and pensions for federal civil servants. The US Department of Transportation (DOT) utilizes a budget mechanism called contract authority to obligate and spend a predetermined level of funds authorized by Congress from the HTF for highway projects (FHWA 2017, 13).

The Highway Trust Fund was born in the 1950s out of an idea that taxes on a specific group of users, in this case automobile owners, should ultimately benefit those users. This made sense at the time, because in 1960 there was less than one registered highway vehicle for every two Americans in the total population, compared to close to a one-to-one ratio in 2017 (BTS 2019; US Census Bureau 2000, 2017). Representative John Kluczynski (D-IL) introduced the first bill in the House of Representatives in 1953 to establish a HTF containing an efficient level of funding for highways; it called for automatically appropriating revenue from transportation-related excise taxes to a "Federal-Aid Highway Trust Fund," which would then be used specifically for highway projects. Upon introducing the measure, he argued, "Why should not the public that pays the tax from motorized traffic then have the full benefit and assistance that that tax can provide?" (Weingroff 2013b, 4). Kluczynski's idea was eventually included in the Federal-Aid Highway Act of 1956. As Federal Highway Administration (FHWA) historian Richard Weingroff writes, "The word 'trust' allowed highway officials to assure motorists paying this tax that their payments would be used exclusively to improve the Nation's roads" (Weingroff 2013b, 12-13). President Dwight D. Eisenhower signed the Federal-Aid Highway Act into law on June 29, 1956, creating what media outlets would later refer to as the "sacrosanct Highway Trust Fund" (Weingroff 2013b, 12; Weingroff 2013a). Congress expanded the mandate of the HTF to fund mass transit projects as part of the Federal-Aid Highway Act of 1973, to the dismay of those who cherished its sacrosanct nature (Weingroff 2013a). Twenty-six years later, this is the Highway Trust Fund we see today.

Unfortunately, America's neglected highway infrastructure now requires large investments in order to bring it to a state of good condition and mitigate worsening traffic congestion. A critical factor is that the purchasing power of the gasoline tax-the HTF's main funding stream - has eroded by 40 percent since it was last set in 1993 (Varn 2019). The gas tax would have been approximately 11.6 cents higher in 2015 had Congress adjusted it for inflation since then (Kile 2015,9). Confounding factors include costly damages to infrastructure from climate change, "rising fuel efficiency and electric vehicles," and "shifting transportation priorities" (Varn 2019).

The misalignment between this environment and the stagnant federal infrastructure financing structure has caused rankings for American road quality to drop from eighth to eleventh on the World Economic Forum's Global Competitiveness Report (Porter and Schwab 2008; Schwab 2018). The American Society of Civil Engineers has given the US road system a D-range grade in its Infrastructure Report Cards compiled every three to four years since 1998 and, in its 2017 report card, called it "crowded, frequently in poor condition, chronically underfunded," and "dangerous" (ASCE 2017, 76 and 100). 
Meanwhile, Congress has been unwilling to boost HTF revenue accordingly and, as a result, the HTF is increasingly inadequate to meet its obligations. In Fiscal Year (FY) 2008, HTF outlays officially exceeded annual revenue, and Congress enacted several laws to transfer a total of $\$ 114.7$ billion to the Fund between Fiscal Years 2008 and 2018 to supplement its reserves (FHWA 2017, 44-5). These reserves are projected to run dry by Fiscal Year 2022 (CBO 2019), and Congress will then have to initiate increasing general revenue transfers into the HTF each year. Chris Spear, the President and CEO of American Trucking Associations, outlined in a 2018 op-ed why this is a problem: "Lawmakers...can raid the general treasury... to keep the Highway Trust Fund afloat, as has been done several times since 2008. That option relies on us borrowing more money from overseas, driving up our national debt at the expense of future generations" (Spear 2018). In essence, utilizing the HTF as a placeholder for general revenue transfers-rather than financing it independently, as originally intended-reduces the intergenerational equity of road funding by relying on public debt, defeating the original purpose of the Fund.

Three of the most discussed options to keep the HTF solvent include raising the gas tax, developing pilot projects such as a vehicle miles traveled fee or road pricing to raise revenue using alternative means, or reducing federal spending on highways altogether. Lawmakers in Congress could include one or more of these interventions in the reauthorization of the Fixing America's Surface Transportation (FAST) Act, the law that governs surface transportation programs through September 30, 2020 (FHWA 2017), to ensure HTF revenue is sufficient to continue regularly funding infrastructure projects of regional or national significance. However, a more radical approach might involve ending the HTF and funding highways directly through general revenues, as some other countries have done.

\section{INTERNATIONAL INITIATIVES}

\section{JAPAN}

Of the three countries surveyed in this paper, Japan eliminated its dedicated revenue fund for infrastructure most recently. Lawmakers enacted a special road fund in 1953, around the same time the United States established the HTF. The government began earmarking taxes on gasoline and diesel to the fund between 1954 and 1956 (Umeda 2014, 64-5). A 1958 law then codified the Road Improvement Special Account (RISA) more fully and specified the revenues that would fund it and its allowable expenses (Hirai, Wright, and Sorel 2004, 2). The system was "based on the concept that road users who enjoy the benefits of improved roads should bear the burden for their improvement" (quoted in Hirai, Wright, and Sorel 2004, 1). However, a number of political problems began to plague the RISA. A report commissioned by the government found that revenues to the RISA after 2007 had exceeded expendituresthe exact opposite situation currently facing the United States (MLIT 2008). Moreover, urban voters thought of RISA highway expenditures as a redistribution of taxes to the construction industry and to rural members of the conservative Liberal Democratic Party (LDP) (Eno Center for Transportation 2014, 36-8). The Japanese government voted in 2006 to examine the RISA (MLIT 2008), presumably due to the findings of the report and these political pressures. In 2008, LDP Prime Minister Fukuda Takeo introduced legislation-ultimately enacted in 2009-to untie transportation-related taxes from highway funding and send them instead to the general revenue account (Lipscy 2012, 411 and 426; MLIT 2008). Professor Phillip Lipscy 
of Stanford University argues that the measure allowed the LDP to demonstrate broad appeal to the general public by "sever[ing] the explicit connection between transportation taxes and redistribution to traditional LDP supporters" (Lipscy 2012, 411). Appropriations for road projects now flow through the General Fund.

Japan's experience represents a best-case scenario of being able to maintain robust national investment and high road quality after eliminating a dedicated revenue account for infrastructure. National investments in highways have dropped significantly, down from $\$ 55.7$ billion in 2008 to $\$ 34.8$ billion in 2014 (Eno Center for Transportation 2014, 38), but the lower figure is seemingly more efficient for the government in terms of national politics and the actual dollars needed. Japan collected $\$ 24.7$ billion in gas tax revenue in 2010 (Eno Center for Transportation 2014, 37; Poole 2015), meaning that the government contributed more than $\$ 10$ billion for infrastructure from non-transportation taxes flowing into the General Fund and likely allocated the entirety of its gas tax revenue toward the highway system. The Ministry of Land, Infrastructure, Transport, and Tourism (MLIT) has powers that allow for guaranteed multi-year expenditures for certain projects, similar to the contract authority of the US Department of Transportation, which adds greater certainty to the funding process (Eno Center for Transportation 2014, 37-8). Japan's infrastructure has also improved markedly since it eliminated the RISA. The country ranked nineteenth for road quality in the Global Competitiveness Report in 2008 and rose to sixth in the 2018 survey (Porter and Schwab 2008; Schwab 2018). Whether Japan's improved infrastructure is completely due to the abolition of the RISA is up for debate, but the measure at the very least alleviated many of the political issues surrounding the allocation of the earmarked revenue-and it did so without compromising its high road quality.

\section{UNITED KINGDOM}

The United Kingdom ended its program to earmark transportation-related taxes for highways early and quickly. England passed legislation in 1909 establishing a Road Board, following a 1906 recommendation by the Royal Commission on Motor Cars that "the revenue from the taxation of motor-cars is to be devoted to the improvement of roads" (Butcher 2017, 4-5; Spectator 1906). Chancellor of the Exchequer David Lloyd George explained that the Road Board would collect ownership taxes_called Vehicle Excise Duties—on cars and duties on imported oil and allocate those funds for the construction and maintenance of the road system. The Roads Act 1920 then replaced the Road Board with a Road Fund, with high hopes from the Minister of Transport that revenue for the Fund would increase more than eightfold in just over a decade (Butcher 2017, 4-6).

However, improper oversight led the Road Fund to be improperly utilized and, by 1926, drawn from for other purposes (Butcher 2017, 6). In 1936, Winston Churchill, a Member of Parliament at the time, labeled the Road Fund the "Raid Fund" and called for transportationrelated revenues to flow thereafter into the Consolidated Fund. He argued, "It is a monstrous assertion that any important body of taxpayers should claim proprietary rights over the particular quota of taxation which they contribute, and that all should not be brought into an area freely justiciable by the House of Commons" (Parliamentary Debates 1936). Lawmakers passed the Finance Act 1936 to move all revenues from the Road Fund to the general account, and the Miscellaneous Financial Provisions Act 1955 later abolished the Fund entirely (Butcher 2017, 6). 
In a 2015 op-ed, Reason Foundation Director of Transportation Policy Robert Poole called the United Kingdom "the worst-case example of what can happen" when policymakers opt to abolish a dedicated revenue account for highways. Great Britain collects $\$ 45.0$ billion in revenue from fuel taxes that flow "directly into the Consolidated Fund," yet it only spends $\$ 15.3$ billion on surface transportation infrastructure (Poole 2015; Butcher 2017, 6). This means that approximately 66 percent of revenue ends up used for other purposes. In other words, the abolition of the Road Fund led to higher fuel taxes and, ironically, reduced investment in highway infrastructure (Poole 2015). One positive aspect of the British system is that budget mechanisms allow the Department for Transport to receive funds for three years at a time to allow for greater funding certainty (Eno Center for Transportation 2014, 38-9). However, overall, the United Kingdom ranks twenty-sixth globally for road quality in the 2018 Global Competitiveness report and a mere fourteenth in Europe (Schwab 2018). High gas taxes seem to have contributed to the elimination of both the overfunded Japanese and British dedicated revenue streams for infrastructure but, unlike Japan, the abolition of the Road Fund in the United Kingdom led to a serious under-provision of infrastructure at the federal level.

\section{AUSTRALIA}

Australia has had a complicated relationship with earmarking transportation-related excise taxes for highways among the three cases under consideration. The country began earmarking petrol (gas) taxes for highway projects in 1926. In 1959, Treasurer of Australia Harold Holt shepherded the Commonwealth Aid Roads Bill into law, which terminated the previous earmarking agreements. He, like Churchill, generally believed that "it is an unsound practice to allocate the proceeds of any one tax for any particular expenditure in that it cut across the fundamental budgetary principle that all government receipts should be paid into a common account from which particular expenditures can be met by lawful appropriation" (James 1996). He also emphasized that fuel tax revenue fluctuated year-to-year, bringing uncertainty into the highway planning process (James 1996).

By the early 1980s, the level of road funding had dropped drastically as a result of the 1959 measure ending the dedicated fund. After mounting public criticism of the federal government's inadequate expenditures on highways, Australia was ready to earmark revenues once again. In 1982, Parliament established the Australian Bicentennial Road Trust Fund, to be funded by increased taxes on gasoline and diesel (James 1996). A subsequent act tweaked the Fund in 1988, and this program remains the law today. However, beginning in the 19911992 fiscal year, policymakers essentially untied fuel excise taxes from highway funding after incorporating road funding into the budget process. The Bicentennial Road Trust Fund exists today in name only-all transportation-related revenues flow directly into the Consolidated Revenue Fund (Buchanan 2014, 8). There seems to be no legislative push by the government back in the direction of tying transportation excises taxes to highways (Eno Center for Transportation 2014,34 ). The country currently spends approximately $\$ 6.3$ billion annually for highways while collecting approximately $\$ 14.0$ billion annually from transportationrelated excise taxes (Poole 2015), meaning that approximately 55 percent of that revenue ends up used for other purposes.

Just over a decade ago, Australia created what was essentially a quasi-Highway Trust Fund. The Nation-building Funds Act 2008 authorized a special account called the Building Australia 
Fund (BAF) (Department of Finance 2019). Australia's Transport Minister had a significant level of discretion over the utilization of the Fund, and the government made transfers into the BAF from a number of sources, including budget surpluses and the Communications Fund (Eno Center for Transportation 2014, 33-4; Department of Finance 2019). Budget mechanisms allowed for multi-year appropriations plans, like in Japan and England, and payments were made into the BAF after parliamentary consultation of the National Priority List developed by Infrastructure Australia, an independent advisory committee established in 2007 whose board consists of a diverse group of members from "business, academia, and across the public and private sectors" (Eno Center for Transportation 2014, 33-4; Infrastructure Australia, n.d.). The organization publishes its National Priority List of recommended projects after considering proposals from localities, states, and the federal government. The List creates a measure of accountability, as the public can more easily scrutinize any funding that Parliament directs to projects not contained within it (Eno Center for Transportation 2014, 33-4). Future research could look at whether a BAF-style mechanism could be feasible in the United States as a substitute for the HTF, but whether the BAF has been actually effective is unclear, as Australia ranked thirty-fifth globally for quality of roads in 2018, down from thirty-first in 2008 before its implementation (Porter and Schwab 2008; Schwab 2018). The government likely echoed this sentiment, as it passed legislation in 2019 that transferred the balance of the BAF to a new Future Drought Fund focused on drought resilience projects (Future Drought Fund Act 2019).

\section{IMPLICATIONS AND CONCLUSIONS}

Abolishing the Highway Trust Fund entirely is not a new idea in the United States. Senator Ted Kennedy (D-MA) introduced an amendment to what would become the Federal-Aid Highway Act of 1978 to eliminate the HTF (Davis 2018). He argued, "Funding should be subject to the regular authorization and appropriations process. If that process is good enough for our national defense, if it is good enough for our health expenditures, if it is good enough for our education programs, it should be good enough for highways" (124 Cong. Rec. S27120). That proposal failed overwhelmingly in a 10-75 vote on the Senate floor (Davis 2018). The Eno Center for Transportation advocated strongly for the idea in 2014, calling it "a potential longterm solution to our national transportation funding problem" (Eno Center for Transportation 2014 , 45). But critics have always pointed to the certainty for states of a federal expenditure source governed through contract authority and shielded from the political whims of the appropriations process. Robert Poole from the Reason Foundation argues:

If the HTF were abolished... whichever faction held the reins of government would allocate transportation funding according to its latest fancy: high speed rail one term, marine highways another, streetcars yet another, and maybe some highways that passed muster as intermodal connectors. And the idea that a federal government on the road to insolvency would actually invest more in high-priority transportation infrastructure if the link between user payments and spending were abolished strikes me as fanciful (Poole 2015).

The latter point is a warning that eliminating the HTF might cause the United States to follow in the footsteps of a country like England, where abolishing its Road Fund led to a decrease in infrastructure investment and resulted in a painful blow to the quality of its highway system. 
This paper sought to answer whether an insolvency crisis similar to that in the United States caused lawmakers to eliminate their trust funds for federal highway expenditures, and whether these initiatives led to improved infrastructure, funding certainty, and fairness for those who use and benefit from the road system. On the first question, the answer is a definitive no. In Japan, the Road Improvement Special Account brought in revenue far greater than expenditures needed, making the fund seem wasteful to motorists. (This situation may actually serve as a better model for America's frustrations with its Harbor Maintenance Trust Fund.) In England, lawmakers eliminated the Road Fund because it lost its "sacrosanct" nature and was utilized contrary to its original purpose. Australia's earmarking arrangements were subject to criticism from a variety of political interests, but insolvency was not the core justification for their dissolution.

On the second question, the answer is mixed. Japan is the best example of what can happen when a country abolishes an earmarked account for infrastructure. The government consistently delivers strong investments in highways, and road quality has improved significantly in the post-RISA era. England, on the other hand, represents a worst-case scenario. Although budget mechanisms allow for funding certainty, a significant majority of the high fuel taxes benefits non-transportation sectors, and road quality lags compared to other developed countries. Finally, results from the Australian model are difficult to categorize. The Building Australia Fund and Infrastructure Australia seem to have been positive steps toward funding certainty, but it is unclear how well the nation's infrastructure system has actually benefited from these reforms since road quality has decreased since their enactment.

As Congress considers the latest five-year reauthorization of America's surface transportation programs, lawmakers will have to weigh if the Highway Trust Fund today still fulfills its original purpose. Enacting legislation to send transportation excise taxes to general revenues and funding all infrastructure projects thereafter through the regular appropriations process would alleviate many of the insolvency issues surrounding federal highway planning and expenditure. However, such an action could cause increased uncertainty and politicization in infrastructure policy and decreased federal funding. State and local governments in the United States already spend more on highways as a share of Gross Domestic Product (GDP) than the federal government does (Campbell 2020), and they could be forced to contend with a potentially far greater investment as a result of such a change. Chris Spear (2018) writes, "[Lawmakers] could allow the HTF to fail, causing the cancellation or delay of critical transportation projects.... This would force states to do Congress' job... [and] many states ... simply do not have the tax base to replace their federal support." It is also unclear whether Congress could adjudicate regional and local funding spats annually and on multiple fronts. Therefore, any abolition of the HTF in the reauthorization of the FAST Act would need to include multi-year authorizations, and potentially even mandatory appropriations, for critical projects of national importance. If Congress does not raise the gas tax, this may be the only solution that would save our road system in an intergenerationally equitable manner. The only other option is to prohibit general revenue transfers to the HTF in the next surface transportation reauthorization bill in order to force a vote on raising the gas tax in 2021 or 2022 at the brink of the fund's bankruptcy. Any other proposal on the table would either be too early in its infancy by the time the HTF reaches insolvency or would paralyze the highway system entirely. 


\section{Reconsidering the Challenges of Earmarked Taxes for Highways REFERENCES}

124 Cong. Rec. S27120. 1978 (bound ed. August 21, 1978). (Statement of Sen. Kennedy.) https://www. govinfo.gov/content/pkg/GPO-CRECB-1978-pt20/pdf/GPO-CRECB-1978-pt20-4.pdf.

ASCE (American Society of Civil Engineers). 2017. 2017 Infrastructure Report Card: A Comprehensive Assessment of America's Infrastructure. Reston, VA: ASCE. https://www. infrastructurereportcard.org/wp-content/uploads/2016/10/2017-Infrastructure-Report-Card. pdf.

BTS (Bureau of Transportation Statistics). 2019. "Number of U.S. Aircraft, Vehicles, Vessels, and Other Conveyances." Washington, DC: US Department of Transportation, BTS. https://www.bts.gov/ content/number-us-aircraft-vehicles-vessels-and-other-conveyances.

Buchanan, Kelly. 2014. "Australia." In Law Library of Congress, National Funding of Road Infrastructure, 3-13.

Butcher, Louise. 2017. "Vehicle Excise Duty (VED)." Briefing Paper No. SN01482. House of Commons Library (England). https://researchbriefings.files.parliament.uk/documents/SN01482/SN01482. pdf.

Campbell, Sheila. 2020. "Federal Highway Spending and Revenues." Slides presented at the Transportation Research Board Annual Meeting, Standing Committee on Revenue and Finance, January 14, 2020. Congressional Budget Office. https://www.cbo.gov/system/files/202001/56006-CBO-presentation.pdf.

Catrina, Ion Lucian. 2013. "Intergenerational Equity of Public Debt." European Journal of Science and Theology 9, Supplement 2: 167-174.

CBO (Congressional Budget Office). 2019. "Highway Trust Fund Accounts-CBO’s May 2019 Baseline." https://www.cbo.gov/system/files?file=2019-05/51300-2019-05-highwaytrustfund.pdf.

Davis, Jeff. 2018. "Mending or Ending the Highway Trust Fund - the Great Debate of 1978 - Conclusion." Eno Center for Transportation. https://www.enotrans.org/article/mending-or-ending-thehighway-trust-fund-the-great-debate-of-1978-conclusion/.

Department of Finance (Australia). 2019. "Nation-Building Funds." Last updated November 20, 2019. https://www.finance.gov.au/government/australian-government-investment-funds/nationbuilding-funds.

Eno Center for Transportation. 2014. How We Pay for Transportation: The Life and Death of the Highway Trust Fund. Washington, DC: Eno Center for Transportation. https://www.enotrans.org/wpcontent/uploads/2015/09/Highway-Trust-Fund.pdf.

FHWA (Federal Highway Administration). 2017. Funding Federal-aid Highways. Publication No. FHWAPL-17-011. US Department of Transportation, FHWA, Office of Policy and Governmental Affairs. https://www.fhwa.dot.gov/policy/olsp/fundingfederalaid/FFAH_2017.pdf.

Future Drought Fund Act 2019 (Australia). Act No. 55 of 2019. https://www.legislation.gov.au/Details/ C2019A00055.

Hirai, Setsuo, Peter Wright, and Tom Sorel. 2004. Summaries of Road Fund Administrations in Japan, New Zealand, and USA. World Bank. http://siteresources.worldbank.org/INTROADSHIGHWAYS/ Resources/338993-1115316562809/24-road_fund_summaries.pdf.

Infrastructure Australia. n.d. “Who we are." https://www.infrastructureaustralia.gov.au/who-we-are. 


\section{Featured Articles}

James, Denis. 1996. “'Beer and Cigs Up!': A Recent History of Excise in Australia." Background Paper 5, 1995-96. Department of the Parliamentary Library, Parliamentary Research Service, Commonwealth of Australia. https://www.aph.gov.au/binaries/library/pubs/bp/199596/96bp05.pdf.

Kile, Joseph. 2015. "The Status of the Highway Trust Fund and Options for Paying for Highway Spending." Testimony before the Senate Committee on Finance, 114th Congress, June 18, 2015. Congressional Budget Office. https://www.cbo.gov/sites/default/files/114thcongress-2015-2016/reports/50297-transportationtestimony-senate.pdf.

Law Library of Congress. 2014. National Funding of Road Infrastructure. The Law Library of Congress, Global Legal Research Center. https://www.loc.gov/law/help/infrastructure-funding/ infrastructure-funding.pdf.

Lipscy, Phillip Y. 2012. "A Casualty of Political Transformation? The Politics of Energy Efficiency in the Japanese Transportation Sector." Journal of East Asian Studies 12 (3): 409-440. https://doi. org/10.1017/s1598240800008080.

MLIT (Ministry of Land, Infrastructure, Transport, and Tourism) (Japan). 2008. "About Generalization of Road Specific Financial Resources.” [In Japanese.] http://www.mlit.go.jp/road/ir/ir-funds/ minaoshi.html.

Parliamentary Debates (UK). 1936. Commons, Vol. 311, Column 317, April 23, 1936. "Amendment of Law." https://api.parliament.uk/historic-hansard/commons/1936/apr/23/amendment-of-law.

PGPF (Peter G. Peterson Foundation). 2018a. "It's Been 25 Years Since We Last Raised The Gas Tax, and Its Purchasing Power Has Eroded." Last modified December 18, 2018. https://www.pgpf.org/ blog/2018/12/its-been-25-years-since-we-last-raised-the-gas-tax-and-its-purchasing-powerhas-eroded.

- - . 2018b. “The Highway Trust Fund Explained." Last modified June 27, 2018. https://www.pgpf.org/ budget-basics/budget-explainer-highway-trust-fund.

Poole, Robert. 2015. "Don't Abolish the Highway Trust Fund." Reason Foundation. https://reason.org/ commentary/dont-abolish-the-highway-trust-fund/.

Porter, Michael E., and Klaus Schwab. 2008. The Global Competitiveness Report 2008-2009. Geneva, Switzerland: World Economic Forum. www3.weforum.org/docs/WEF_ GlobalCompetitivenessReport_2008-09.pdf.

Schwab, Klaus. 2018. The Global Competitiveness Report 2018. Geneva, Switzerland: World Economic Forum. http://reports.weforum.org/global-competitiveness-report-2018/.

Spear, Chris. 2018. "Highway Trust Fund Is on Fumes and Time Is Running Out." The Hill, May 14, 2018. https://thehill.com/opinion/white-house/387629-highway-trust-fund-is-on-fumes-and-time-isrunning-out.

Spectator. 1906. “The Report of the Royal Commission on Motor-Cars Was Issued." July 28, 1906, 3. http://archive.spectator.co.uk/article/28th-july-1906/3/the-report-of-the-royal-commission-onmotor-cars-w.

Umeda, Sayuri. 2014. “Japan.” In Law Library of Congress, National Funding of Road Infrastructure, 60-66.

US Census Bureau. 2000. "Historical National Population Estimates: July 1, 1900 to July 1, 1999." Washington, DC: US Census Bureau, Population Division. https://www2.census.gov/programssurveys/popest/tables/1900-1980/national/totals/popclockest.txt. 
- - . 2017. "Annual Estimates of the Resident Population: April 1, 2010 to July 1, 2017." Washington,

DC: US Census Bureau, Population Division. https:/factfinder.census.gov/faces/tableservices/ jsf/pages/productview.xhtml?pid=PEP_2018_PEPANNRES\&src=pt.

Varn, Jake. 2019. “The Highway Trust Fund Has a Numbers Problem.” Bipartisan Policy Center, May 24, 2019, https://bipartisanpolicy.org/blog/the-highway-trust-fund-has-a-numbers-problem/.

Weingroff, Richard. 2013a. "Busting The Trust." Public Roads 77, no. 1 (publication no. FHWAHRT-13-005). Federal Highway Administration. https://www.fhwa.dot.gov/publications/ publicroads/13julaug/03.cfm.

- 2013b. Busting The Trust: Unraveling the Highway Trust Fund 1968-1978. Federal Highway Administration. https://www.fhwa.dot.gov/highwayhistory/busting_the_trust.pdf. 
DAVID GELLMAN is a second-year MPA candidate at the Trachtenberg School, concentrating in Politics, Policy, and Administration. Originally from Miami, Florida, David graduated from Georgetown University with a BA in Government and a minor in Spanish. After college, David served as an aide in the U.S. House of Representatives and has spent the last three years lobbying the federal government on behalf of cities across the country.

\section{ACKNOWLEDGEMENTS}

The author is incredibly grateful for his editorial team, especially Elisa Walker, his brilliant Associate Editor, and Jackie Wheeler, his Managing Editor and friend whose professionalism and cheer were integral to this process. He would also like to thank Professor Marvin Phaup, whose feedback and support helped take this paper to the next level. He is so proud of what we have accomplished together. 